\title{
New onset diabetes mellitus after liver transplantation
}

\author{
Benedict Maliakkal ${ }^{1}$, Sanjaya K. Satapathy ${ }^{2}$ \\ ${ }^{1}$ Ascension St. Thomas Hospital, Nashville, TN, USA; ${ }^{2}$ Donald and Barbara Zucker School of Medicine at Hofstra/Northwell, Northwell Health, \\ Hempstead, NY, USA \\ Correspondence to: Sanjaya K. Satapathy, MBBS, MD, DM, MS (Epi), FAASLD, FACG, AGAF, FASGE. Medical Director, Liver Transplantation, \\ Division of Hepatology at Sandra Atlas Bass Center for Liver Diseases \& Transplantation, Professor of Medicine, Barbara and Zucker School of \\ Medicine/Northwell Health, 400 Community Drive, Manhasset, NY 11030, USA. Email: ssatapat@northwell.edu. \\ Comment on: Man Kim J, Hwang S, Lee KW, et al. New-onset diabetes after adult liver transplantation in the Korean Organ Transplantation Registry \\ (KOTRY) study. Hepatobiliary Surg Nutr 2020;9:425-39.
}

Submitted May 26, 2021. Accepted for publication Jun 08, 2021.

doi: $10.21037 / \mathrm{hbsn}-21-214$

View this article at: https://dx.doi.org/10.21037/hbsn-21-214

The recently published article, "New-onset diabetes after adult liver transplantation in the Korean Organ Transplantation Registry (KOTRY) study" by Man Kim et al. has generated significant renewed interest in New Onset Diabetes after Transplant (NODAT) (1). NODAT was defined by International Consensus (2003) and by American Diabetes Association by the same criteria as Type 1/Type 2 diabetes. Anyone after liver or another solid organ transplantation (SOT) on antidiabetic medication for more than one month or who fulfills one of these criteria on stable immunosuppression is deemed to have NODAT: (I) fasting blood sugar (FBS) $>7 \mathrm{mmol}(126 \mathrm{mg} / \mathrm{dL}$ ); (II) random blood sugar (RBS) on two occasions or a 2-hour blood sugar on a 75 -gm oral glucose tolerance test (OGTT) of $>11.1 \mathrm{mmol}$ (200 mg/dL); (III) HbA1c >6.5\% (2). Unfortunately, this definition lumps together, patients with varying degrees of pancreatic $\beta$ cell dysfunction and Insulin resistance. This is problematic both in terms of optimizing individualized care and preventing/predicting development of complications downstream. Measuring Insulin levels along with glucose levels during a 2-hour OGTT will be able to better define the mechanism(s) involved in the causation of hyperglycemia and help with tailoring management (3).

HbA1c significantly underestimates average blood sugars in post liver transplant patients, especially in those with congestive splenomegaly and therefore it should not be used for diagnosis or management of NODAT. Many experts are considering change of terminology back to Post Transplant Diabetes Mellitus (PTDM) as a significant number of patients may have undiagnosed DM and in most NODAT patients, the risk factors for development of DM are present pre-transplantation (4).

The incidence of NODAT varies significantly among studies of NODAT in the 3 major solid organ transplants due to varying definitions and ranges from $10-40 \%$ over $1-5$ years for liver transplantation. Highest incidence $(80 \%$ of total) is in the first 6-12 months after transplantation. It drops to about 3-4\% per year for the next 4 years (1). Liver transplant patients have relatively low induction and maintenance Immunosuppressant use. Also, unlike heart and kidney, it is the organ most involved in sugar and energy metabolism. As the new organ functions better, and the portal blood flow is corrected, the donor liver should have a major protective effect on the recipient. Hence, LT should have the lowest incidence of NODAT among SOT. So far, there is precious little published to explain why this is not actualized.

\section{Mechanism/s of causation of NODAT/PTDM}

(I) A fertile soil of insulin resistance with obesity, family history of diabetes and sarcopenia is present in most patients even before liver transplantation.

(II) Impact of immunosuppression on $\beta$ cell mass and function (5) (calcineurin and mTOR inhibitors) and simultaneous increase in Insulin resistance in the muscle, adipose tissue and liver produced by glucocorticoids is unique to transplant and is the most important driver in the first 3 months post liver transplantation when the seed of NODAT is sowed. 
(III) Dysfunction of the donor liver due to any cause: (i) preexisting hepatitis $\mathrm{C}$ infection; (ii) donor age, diabetes and liver steatosis; (iii) ischemia reperfusion injury (as in donation after circulatory death); (iv) vascular or biliary complications (v) opportunistic infections such as CMV; (vi) rejection both acute and chronic.

(IV) Post-transplant weight gain: the maximum rate occurs between 3 months and 1-year post-transplantation (and it is generally more adipose tissue than lean body mass) and so it is not surprising that the incidence of NODAT is also the highest during this period (6).

(V) Impact on morbidity and mortality in liver transplantation: Many single-center and most registry studies overall suggest worse graft and patient outcomes associated with NODAT/PTDM. The graft outcomes likely influence NODAT more than viceversa. Infections, renal and cardiovascular outcomes are worse in patients with NODAT/PTDM. However, the problem is quite complicated-there is a lot of interplay between rejection/immunosuppression and NODAT/PTDM and therefore a direct cause and effect of diabetes with outcomes is difficult to prove without more granular data. Longer and more well designed and multicenter studies controlled for age ethnicity and immunosuppression are needed.

\section{Prevention and management of NODAT}

Age, BMI, African and Hispanic race, presence of Hep C, prediabetes, family history of T2DM and sarcopenia are pre-transplant risk factors for developing NODAT/PTDM.

In patients with two or more risk factors, periodic monitoring with weight, BMI, fasting glucose and Insulin levels at one month post transplantation and monthly till 3 months and then Q 3 monthly till 1 year and Q 6 monthly thereafter can identify patients at high risk for NODAT/PTDM. OGTT with Insulin level measurement periodically is ideal but may be inconvenient and expensive.

Those prediabetic and insulin resistant can be targeted for intensive global management. The same strategy should be employed in all patients discharged on Insulin or other anti-diabetic therapy after transplantation. Weekly consultation by transplant dietician with patient/caregiver can be most helpful in the first month.

The donor factors are not controllable, so also biliary/ vascular complications and unexpected rejection. These can increase risk for NODAT/PTDM directly or indirectly.

Using Induction therapy that avoids or minimizes corticosteroids in high-risk patients. Early addition of Mycophenolate can help wean steroids without risking rejection. Also, with this strategy, most patients can be managed with tacrolimus dosing to achieve trough levels under $7-8 \mathrm{ng} / \mathrm{mL}$.

Limiting glucose in IV fluids especially in those on steroids, minimizing sugar in tube feeds and nutritional supplements along with a diabetic diet can decrease the insulin requirements early post- transplantation and decrease pancreatic $\beta$ cell exhaustion. Use of continuous glucose monitoring (CGM) devices once approved in the hemodynamically stable inpatients will go a long way in achieving euglycemia along with diet and short acting insulin in the inpatient setting.

If possible, would use extended-release Metformin at tolerated doses with DPP-4 inhibitors/GLP-1 agonists in those who are hyperglycemic at discharge along with a strict no sugar/low carbohydrate diet and CGM for monitoring so that weaning from Insulin over the next 3 months is made a major priority. Lowering the blood Insulin levels while keeping blood sugars controlled, will decrease (fat) weight gain and decrease NODAT/PTDM during the first year after transplantation when they are at the highest risk. An approach to management of NODAT/PTDM in the first year after LT is presented in the Figure 1.

\section{Conclusions}

Heightened awareness among patients, caregivers and hepatologists of NODAT/PTDM and its consequences can lead to optimal and individualized management. This will decrease its incidence, even reverse/resolve the problem in a significant majority and thus improve long term outcomes.

\section{Acknowledgments}

Funding: None.

\section{Footnote}

Provenance and Peer Review: This article was commissioned by the editorial office of Hepatobiliary Surgery and Nutrition. The article did not undergo external peer review.

Conflicts of Interest: Both authors have completed the ICMJE 
- Address obesity and sarcopenia if possible re-liver LT

- At this time donor risk factors cannot be addressed, however would try to avoid transplanting livers from donors who are diabetic and/or with $>30 \%$ steatosis to patients with DM2/NAFLD

- Minimize steroids and use thymoglobulin/basiliximab if possible

- Minimize glucose in IV fluids and sugar/carbohydrates in the diet. Use basal and pre meal insulin to keep blood sugars in the $100-200 \mathrm{mg} / \mathrm{dL}$

- Use MMF early and keep tacrolimus trough level below $8.5 \mathrm{ng} / \mathrm{mL}$. Bring prednisone dose down to $10 \mathrm{mg} / \mathrm{day}$ within 2 weeks post transplantation

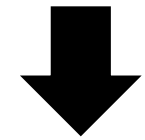

\begin{tabular}{|c|c|c|c|c|}
\hline & No hyperglycemia & Transient hyperglycemia & Persistent hyperglycemia & Pre-transplant DM2 \\
\hline 0 week & No medication & Low dose metformin ER & $\begin{array}{l}\text { Metformin + DPP-4 + } \\
\text { lowest dose Insulin }\end{array}$ & $\begin{array}{l}\text { Metformin + GLP-1 + } \\
\text { lowest dose Insulin }\end{array}$ \\
\hline $\begin{array}{l}1-4 \\
\text { weeks }\end{array}$ & $\begin{array}{l}\text { Weekly dietary } \\
\text { counsel + FBS/ } \\
\text { insulin level }\end{array}$ & $\begin{array}{l}\text { Weekly dietary counsel + } \\
\text { FBS/insulin }\end{array}$ & $\begin{array}{l}\text { Weekly dietary counsel + } \\
\text { wean insulin gradually }\end{array}$ & $\begin{array}{l}\text { Weekly dietary counsel + } \\
\text { wean insulin gradually }\end{array}$ \\
\hline $\begin{array}{l}4-12 \\
\text { weeks }\end{array}$ & $\begin{array}{l}\text { Monthly dietary } \\
\text { counsel + FBS/ } \\
\text { insulin* }\end{array}$ & $\begin{array}{l}\text { Monthly dietary counsel + } \\
\text { FBS/insulin }\end{array}$ & $\begin{array}{l}\text { Monthly dietary counsel } \\
+ \text { FBS/insulin level + } \\
\text { weight loss measures }\end{array}$ & $\begin{array}{l}\text { Quarterly dietary counsel } \\
+ \text { weight loss measures } \\
\text { + wean insulin gradually }\end{array}$ \\
\hline $\begin{array}{l}>12 \\
\text { weeks }\end{array}$ & $\begin{array}{l}\text { Monthly dietary } \\
\text { counsel + FBS/ } \\
\text { insulin* }\end{array}$ & $\begin{array}{l}\text { Monthly dietary counsel + } \\
\text { FBS/insulin }\end{array}$ & $\begin{array}{l}\text { Quarterly dietary counsel } \\
+ \text { weight loss measures } \\
+ \text { wean insulin gradually }\end{array}$ & $\begin{array}{l}\text { Quarterly diet counsel + } \\
\text { weight loss measures + } \\
\text { wean insulin }\end{array}$ \\
\hline
\end{tabular}

*, consider OGTT + insulin.

Figure 1 Post-transplant diabetes mellitus prevention and management.

uniform disclosure form (available at https://hbsn.amegroups. com/article/view/10.21037/hbsn-21-214/coif). Dr. SS has served as a speaker for Intercept, Alexion, Dova, as an advisory board member for Gilead, Intercept, Bayer and has received research funding from Novartis, Fibronostics Gilead, Biotest, Genfit, Conatus, Intercept, Shire, Exact Sciences, Eananta, Dova, Bayer. Sanjaya K. Satapathy is an employee of Northwell Health. The other author has no conflicts of interest to declare.
Ethical Statement: The authors are accountable for all aspects of the work in ensuring that questions related to the accuracy or integrity of any part of the work are appropriately investigated and resolved.

Open Access Statement: This is an Open Access article distributed in accordance with the Creative Commons Attribution-NonCommercial-NoDerivs 4.0 International License (CC BY-NC-ND 4.0), which permits the non- 
commercial replication and distribution of the article with the strict proviso that no changes or edits are made and the original work is properly cited (including links to both the formal publication through the relevant DOI and the license). See: https://creativecommons.org/licenses/by-nc-nd/4.0/.

\section{References}

1. Man Kim J, Hwang S, Lee KW, et al. New-onset diabetes after adult liver transplantation in the Korean Organ Transplantation Registry (KOTRY) study. Hepatobiliary Surg Nutr 2020;9:425-39.

2. Davidson J, Wilkinson A, Dantal J, et al. New-onset diabetes after transplantation: 2003 International consensus guidelines. Proceedings of an international expert panel meeting. Barcelona, Spain, 19 February 2003.

Cite this article as: Maliakkal B, Satapathy SK. New onset diabetes mellitus after liver transplantation. HepatoBiliary Surg Nutr 2021;10(5):724-727. doi: 10.21037/hbsn-21-214
Transplantation 2003;75:SS3-24.

3. Sharif A, Moore RH, Baboolal K. The use of oral glucose tolerance tests to risk stratify for new-onset diabetes after transplantation: An underdiagnosed phenomenon. Transplantation 2006;82:1667-72.

4. Sharif A, Hecking M, de Vries AP, et al. Proceedings from an international consensus meeting on posttransplantation diabetes mellitus: recommendations and future directions. Am J Transplant 2014;14:1992-2000.

5. Dai C, Walker JT, Shostak A, et al. Tacrolimus- and sirolimus-induced human $\beta$ cell dysfunction is reversible and preventable. JCI Insight 2020;5:e130770.

6. Beckmann S, Ivanović N, Drent G, et al. Weight gain, overweight and obesity in solid organ transplantation--a study protocol for a systematic literature review. Syst Rev 2015;4:2. 